\title{
Classroom Interaction in Teaching English as Foreign Language at Lower Secondary Schools in Indonesia
}

Hanna Sundari*

The Faculty of Language and Arts, Universitas Indraprasta PGRI, Jalan Nangka No. 58 C, South Jakarta, Indonesia

Corresponding Author: Hanna Sundari, E-mail: hanna.sundari@unindra.ac.id

\section{ARTICLE INFO}

Article history

Received: September 24, 2017

Accepted: November 16, 2017

Published: December 30, 2017

Volume: 8 Issue: 6

Advance access: December 2017

Conflicts of interest: None

Funding: None

\author{
Key words: \\ Classroom Interaction, \\ Language Classroom, \\ English Classroom, \\ Foreign Language, \\ Secondary School
}

\begin{abstract}
The aim of this study was to develop a deep understanding of interaction in language classroom in foreign language context. Interviews, as major instrument, to twenty experienced English language teachers from eight lower secondary schools (SMP) were conducted in Jakarta, completed by focus group discussions and class observation/recordings. The gathered data was analyzed according to systematic design of grounded theory analysis method through 3 -phase coding. A model of classroom interaction was formulated defining several dimensions in interaction. Classroom interaction can be more comprehended under the background of interrelated factors: interaction practices, teacher and student factors, learning objectives, materials, classroom contexts, and outer contexts surrounding the interaction practices. The developed model of interaction for language classroom is notably to give deep descriptions on how interaction substantially occurs and what factors affect it in foreign language classrooms at lower secondary schools from teachers' perspectives.
\end{abstract}

\section{INTRODUCTION}

Classroom interaction has been a central issue in teaching and learning English in the era of communicative language teaching. A number of articles and books related to comprehensible input, output, and interaction in second language acquisition (Ellis, 1991; Krashen, 1989; Larsen-Freeman \& Long, 1991; Mackey, Abbuhl, \& Gass, 2012; Swain, 2000) have given great contributions for language teaching and learning. Besides, the research dealt with teacher talk, students response and feedbacks, also called as a classroom discourse, has been widely published and discussed among language teachers/educators, researchers and experts (Liskinasih, 2016; Maolida, 2013; Roostini, 2011; Walsh, 2011). However, classroom interaction in a foreign language context for secondary schools particularly based on teachers' perspectives seems to have less attention.

In the field of second language acquisition, negotiation of meaning through modified input occurs in interactional conversation. Conversational negotiation and linguistic adjustment provides comprehensible input that is integrated into acquired language (Mayo \& Soler, 2013). According to (Ellis, 1991), second language is acquired in 3 phases. The first is noticing linguistic features (input) related to shortterm memory and perception; the input is then called an initial intake. Comparing the old and new linguistic features is the second phase in acquiring the second language. The last is when the language learner develops new hypothesis based on the comparison of old and new input and store it as a final intake. Then, Van Lier (in Hermanto, 2015) added that interaction mediates input and intake with meaningful activities; therefore, it is prominent to facilitate acquisition. Not only input, Swain wrote that comprehensible input is not sufficient enough if the language learner does not have ample opportunities to use the language (Mackey et al., 2012). By output, language learners should be aware of identifying linguistic error and reconstructing production of language. To have these views in mind, the teacher in language classroom plays a critical role to provide comprehensible input as well as to give a plentiful room for students to speak and write the language by setting various interaction modes in the classroom.

Taking into account the contexts where the language learners acquire the language, sociocultural views of language learning defines language and social interaction between people are inextricable. Thoms (2012) summarized, in sociocultural theoretical view, the major aspects of language are tied and formed by the strategies in which people interact with others in various communicative contexts. He 


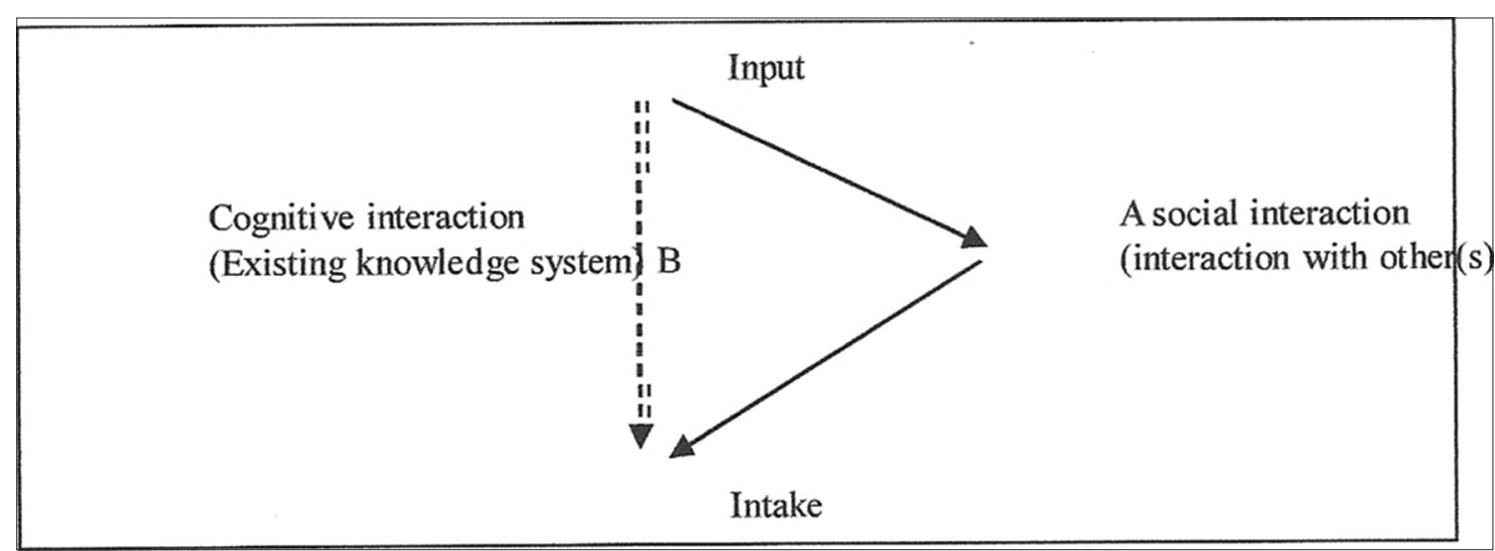

Figure 1. The Role of Interaction (Van Lier, 1988)

also added that language learners develop their competences in social interactions and relationships via participation in communication with more experienced, knowledgeable, and competent participants, such as teacher and/or peer (Thoms, 2012). The roles of teachers and/or peer in foreign language classroom are to guide and assist in completing linguistic tasks and language production through interaction.

Related to language learning in various social contexts, classroom, as one of social contexts, is a small society consisting of teacher and learners with a specific cultural system in which roles, functions, and goals are different among them. According to Seedhouse \& Jenks (2015), language classroom is a place that aspects of language are learnt and taught, method, syllabus and materials are applied, theories and practices are met, social identity and affective factors are affected, and classroom is a site where interaction and education unite. In the other words, interaction practices occurring inside the classroom are apparently influenced by factors outside the classroom. Moreover, classroom interaction can be defined as institutional talks that is locally organized into conversational exchanges system cooperatively (Markee \& Kasper, in Kharaghani, 2013). In the classroom, controls are on the teacher' hand as the knower; she modifies and simplifies her utterances to help students understand the language easily; she frequently gives feedbacks or correction when students make errors; then, the common interaction pattern follows the moves on teacher initiates communication, students respond and teacher gives feedback (Murray \& Christison, 2011; Ur, 2009; Walsh, 2011). Then, everything in the classroom requires the use of language. Walsh (2011) stated that learners access new knowledge, acquire and develop new skills, identify problems, and establish and maintain relationship through language in interaction. Particularly in language classroom, interaction is viewed as central of language learning and teaching. The language used is as both the object of study and the medium of instruction (Long, 1983 in Walsh, 2011). The teacher and students use the language in interaction in the classroom as the learning goal.

Moreover, interaction in language classroom has been investigated and analyzed using various approaches by some researchers and language experts. The brief summary of recent studies in classroom interaction is as following Table 1.
In addition to studies above, Consolo (2006) presented analysis of teacher talk and student speech, and students' views on communication practices in foreign language classrooms at a state university in Brazil. Then, he pictured a model of classroom interaction in foreign language lessons involving a scope of facts and factors. In the classroom, the relation between teacher and students is asymmetrical. When doing whole-class interaction, the students face limitations in their oral proficiency. Teacher is expected to have competence in managing classroom to encourage student participation to help their oral language development. The research also found the sociolinguistic environments, such as student need, cultural aspect, linguistic aspect, and psychological aspect may influence language development. Similarly, the other element - content, motivation, comprehension, production, negotiation - might provide for conditions to foster foreign language development.

Classroom interaction involves teacher and students as interactants in using target language. In the classroom, communication is mostly initiated and maintained by the teachers. They, as a key holder of classroom communication, play prominent roles to manage the classroom participation and stimulate student language production. Their perspectives related to language classroom practices need to be discovered to comprehend what actually happens in the classroom. Interaction, in the terms of input, output and interaction, in second classrooms has been widely discussed by researchers; nonetheless, most research has been taken place in Western cultural settings (Hall, 2011). Meanwhile, classroom discourse in the particular area to fully understand how sociocultural aspect and societal belief outside the classroom shape classroom interaction inside at foreign language contexts is fewer and needed (Thoms, 2012). The majority studies in classroom discourse have conducted exclusively for adult language learners as participants; whereas only a few research explores classroom communication in middle schools context and teacher engagement in foreign language (Thoms, 2012). Therefore, this current research aims to address the following research questions:

1) How does classroom interaction take place in English as foreign language classrooms at lower secondary schools based on teachers' perspectives?

2) What factors extensively affect classroom interaction in English as foreign language classrooms at lower secondary schools based on teachers' perspectives? 
Table 1. Recent Studies of Classroom Interaction (Walsh, 2011)

\begin{tabular}{lll}
\hline Writers & Contexts & Concepts \\
\hline Van Lier (1988) & L2 Classroom interaction & Four types of L2 classroom interaction \\
& Less topic-orientation, less activity-orientation \\
& More topic-orientation, less activity-orientation \\
& More topic-orientation, more activity-orientation \\
Jarvis \& & Primary-level EFL Lessons & Pedagogic-orientation, more activity-orientation \\
Robinson (1997) & & Show acceptance of pupils' utterances \\
& & Model language \\
& & Give clues \\
& & Elaborate and build up the discourse \\
Kumaravadivelu (1999) & Clarify understandings \\
& A framework of Critical Classroom & Disconfirm or reject \\
Discourse Analysis (CCDA) & The framework reflects the external and internal factors \\
Conversation Analysis on turn-taking & of classroom discourse \\
& Four classroom contexts \\
& and sequence & Form and accuracy contexts \\
& & Meaning and fluency contexts \\
& & Task-oriented contexts \\
& & Procedural contexts \\
& L2 classroom context using & L2 classroom modes \\
& conversation analysis & Managerial \\
& Materials \\
& Skills and systems \\
& Classroom context \\
\hline
\end{tabular}

\section{RESEARCH METHOD}

The method used to accommodate this study is known as grounded theory. According to Creswell, grounded theory method is "a systematic, qualitative procedure used to generate a theory that explains, at a broad conceptual level, a process, an action, or an interaction about substantive topic" (Creswell, 2012). It is used to give deep explanation and explain high complexity of the phenomenon for specific population where the existing theories perhaps do not address the problem clearly. Participants in this study were twenty experienced English language teachers from eight lower secondary schools (SMP) in Jakarta. They were comprised three male teachers and seventeen female teachers who have been teaching English around three to thirty-six years in all grades. With lots of experiences, the participants could be assumed to have knowledge, capability and feasibility to provide information, experiences and opinions about interaction in their classrooms.

To collect the data, 12-recorded semi-interviews were the major instrument, completed by 2 focus group discussions and 13 classroom observation/recordings throughout six months of collecting and analyzing data. Pilot interview was undertaken to test, if necessary, modify the questions. At first, the researcher initiated by asking general question, such as "could you tell me how you interact with students in the class?". Due to a beginner in grounded-theory analysis, the researcher conducted classroom observation/recording in the first phase as preliminary study to narrow research focus. Using FLINT protocol analysis of classroom interaction (Moskowitz, in Brown, 2007: 216-218), classroom observations were then followed by interviews and focus group discussion. The latter was held due to the participants' restricted time to conduct one-by-one interviews. The interviews were transcribed verbatim and respectively analyzed; at the same time, memos/journals were carefully noted at any time the data gathered until the model emerged.

From three types of grounded theory designs, systematic design by Strauss and Corbin was chosen since this structured approach of three-phase coding is more ideal for beginner (Creswell, 2012: 430). In the first phase, called open coding, the data were identified, labelled and named line-byline, phrase-by-phrase, sentence-by-sentence or expression into codes to represent the participants' opinions, attitude, action, thought, feeling, beliefs and patterns. Then, the codes were formulated into categories and sub-categories. At axial coding, the categories were reformulated and related to other categories in six related paradigms (causal, context, core category, intervening, strategies, and consequences) (Creswell, 2012: 426). The third phase, selective coding, consisted of combining the categories together into a model and conceptualizing the interrelated categories into an abstract explanation of classroom interaction. Instead of sequential steps, the collecting and analyzing data was a zigzag process, taking back and forth to constantly reexamine the old and new data, categories and developed model.

\section{FINDINGS}

In this section, it is firstly reported the description of the core category emerged from the data, labelled as classroom interaction practices. The classroom interaction occurs in di- 
mensions of verbal, non-verbal, personal and pedagogical practices. Then, teacher and student factors, learning objectives and content materials, classroom context and outer context are discussed as factors may influence teacher preferences during interaction with the students.

\section{Description}

Just like the other days, this morning I enter the classroom and greet all the students "Good morning, class!". Not to wait so long, they reply loudly, "Good morning, mam!" and sit nicely on their chairs. Another opening activity is asking them who is absent today and whether they have done their homework. Sometimes I set up my materials on the laptop and prepare it. Another time, I assign them to do language practices from the course-books. Otherwise, I bring teacher-made worksheet that I prepare the day before. The quantity, class size, time allocated, topics/materials and the difficulty level are several aspects to consider. In reading section, the students mostly interact with books and exercises. Meanwhile, I facilitate them to interact each other through pair and group work particularly in speaking section. However, at the end of the year, I teach to make them ready for examination and continuing higher level of education. During the class, I mostly give them instructions and directions to do many activities. Furthermore, to get them involving in the lesson and make them speak, I deliver lots of questions. They are able to answer the questions though I expect more varieties and responses. Whatever the responses they give in the class, I do not forget to praise them. I think giving a compliment will motivate them to learn more. Besides, a good model of language is also important. Accordingly, I frequently choose one of the excellent student in the class as a model. To break the boredom and build rapport, I incidentally put in humors even though I personally believe that I am not a humorous person. To interact with students in the language classroom, several aspects need to take into account either inside or outside the class.

Interaction in the classroom is mostly initiated by teacher through oral communication. Combining first and target language, teacher gives directions, presents materials, asks questions, delivers grammatical items, and corrects student error. It is called as verbal interaction practice. Not only verbal dimension, interaction also involves eye-contact, facial expression, and gesture as non-verbal dimension. To manage unpredictable situation and disruptive behavior, teacher sometimes warn and motivate the students as pedagogical practices in classroom interaction. Giving compliment and humors in the classroom are the sign of personal interaction practices in building rapport. Most teacher believe that the students, as beginning language learners, still need time to improve their language proficiency, particularly production. They think their main goals of learning are giving first positive impression to learn English and preparing the students for examination. They are certain the students comprehend what the teachers teach though they are not enough sufficient to produce the language orally. The set of belief system perceived by the teacher might influence their preferences in classroom interaction practices.

\section{Interaction Practices}

Classroom interaction are categorized into verbal practices, non-verbal practices, pedagogical practices and personal practices. The majority of teachers said that they combine first and target language. Other teachers prefer to use mostly in first or target language. For easiness and quickness, G3 and G14 generally use Indonesian as medium of instruction.

Once I try to use English, yet they do not understand what I am saying. Then, I think I rather choose to use Indonesian than keep consistent in English. (TW-07).

Other dimensions in verbal practices are teacher talk, teacher questions, error correction, student response and student question. Teacher talk is dominated over classroom communication. Slow, clear and loud pace with simple expression is the characteristic of teacher talk. Teachers also deliver questions mostly in the form of displayed questions. Regarding to error correction, some teachers prefer to repair error made the students; meanwhile, other choose to ignore it. The teachers described differently about the student response. Most of them stated that student response particularly oral language in English is still limited in the form of short expression.

Yes, the students are asked to produce writing product in English. However, in the process of making the product, they use Indonesian, it doesn't matter for me. That is the level of the student. If their levels are all good in English, they can speak English. (TW-02).

Teacher also yielded that some students ask questions when necessary. As the students do not understand what they should do and they find problems of vocabulary, they come to the teachers for help. The teachers reported that what they communicate with the students not only about materials or subject. Moreover, giving advices, suggestions, warning as well as compliment are also part of interaction practices.

It is so important. The student feels that my teacher appreciates me by giving compliment. For next, she will learn more and more. That is so important. (TW-FGD-02).

We say good job or you can do it. Students (teenagers) love to be praised. (TW-02).

The teachers believe that at this present the students, as beginners, provide limited language production. By the time, they gradually develop their language proficiency.

\section{Teacher and Student Factors}

The way teacher manages the class and communicate with the students and the way students respond it are determined by some factors. The teachers described that the teacher's language proficiency may influence how she interacts with the students and the student response.

I think it is such as an endless circle. At first, teacher thinks that the students are low proficient; therefore, she decides to use Indonesian. At the same time, the students find the teacher never speaks English, so they then feel why I should try to use it. It becomes an endless circle. (TW-03).

In addition to language proficiency, the teachers revealed that pedagogical competence, experience and personality may also influence interaction practices. 
At my first year of teaching, I gave lots of lectures because I was still confused what to do during the lessons. But now, I always find ways how to treat them... (TWFGD-01).

...if the teachers are lack in giving materials, lack of experiences and lack of knowledge, it (the teaching process) will be offhanded. (TW-05).

Moreover, teachers realized that teaching experience in various classes will enhance their skill of managing classroom and building communication and interaction with the students. They also perceived that each class, likewise each person, is unique, so is the interaction practice, even with the same teacher.

The same teacher in different classes will shape different interaction. (CW-04).

The teachers described that student response in interaction is influenced by various factors, such as level of proficiency, characters, intelligence, confidence, and motivation. Low proficient students will provide limited response even though the teacher believe they are good at comprehension.

At least, they give response (in Indonesian). It indicates that they understand the meaning. (CW-01).

Some teachers said that the students' language proficiency in their classes are very low. It becomes constraint in communication and interaction. On the other side, some teachers reported that confidence and intelligence are related to student response.

They have confidence because they are smart, because they know (the materials). if not, they will be silent and anxious. We can see that students who are low keep in silence. Usually, the students who yell out loud (to answer teacher's question) are good (smart) even though their speaking is disorder and messy. I still appreciate it. (TW-12).

Some teachers described that their students are high-motivated, and it makes the process of communication and interaction in teaching learning process easier. Meanwhile, some teachers reported that their students are not interested in learning English and do not provide expected responses. This situation brings problems to communication and interaction.

\section{Learning Objectives and Content Materials}

The teachers revealed that each grade has specific objectives of language skill based on mandated curriculum and syllabus. The desired objectives and specific skill will determine the classroom activity and communication set by the teachers.

In grade 9, it will focus on national examination, so reading section is major activity. Speaking and listening activity are neglected... (TW-03).

...it is not for communication. I think my goal is much more to reading comprehension. It helps them to continue to the higher level of education... (TW-12).

The teachers said that the content materials discussed in each meeting and the level of difficulty might influence how the students interact in the classroom.

It depends on the materials. It will be individual work or group...(TW-FGD-02).
This (pointing out the course-book) is just a piece of cake for grade 9 ... (TW-12).

Most of the teachers also believe that interaction between teacher and students will get highest on content materials for speaking skills where oral communication is most required.

\section{Classroom Contexts}

Classroom context in interaction, as category emerged from data, refers to overall elements dealt with classroom. Teachers described several contexts affect the way they interact with students. They are grades, class size, class composition, duration, classroom climate, and learning facility. Several teachers reported that they treat each class and grade differently. Types of questions, compliment, treatment and classroom activity are dissimilar among the grades.

It is different. For grade 7, they were already graduated from primary schools, so they could understand short, simple expressions. Gradually they get higher class, the language expressions are more complex. Then, when they are in grade 9, their language will be more difficult and complex. (TW-05).

Most of the teachers also revealed that class size has influenced interaction in the classroom. Large classes make them to choose whole-class interaction since they do not enough time to interact with students one by one.

When we test several students orally, then what about the others? The class will be so noise. Even though I had assigned them to do something, it was still so much noise. They could not be controlled. (TW-12).

Even not all teachers agree, class composition seemingly affects the way student interact in the classroom. Some teachers said that mixed-heterogenous class, such as high students and low students, fairly determines interaction as well as gender composition.

Heterogeneous class in which high and low students, or disruptive and obedient students, are together causes difficulty for teacher to manage the class and select activity. (CW-FGD-02).

Moreover, most teachers described interaction in English in the classroom takes a lot of time. In fact, the duration is quite limited for each session.

For example, they act out dialogue. If we focus on accuracy, it needs more than one session... We need to revise their vocabulary and pronunciation. It will take a lot of time because they are more than forty students each class, just four hours in a week... (TW-07).

Some teacher also said that learning facility in the classroom is very helpful learning process in general, and specifically for interaction with the students. Video, film, picture, music and photos are not only facilitating learning language but also stimulating students to give more responses.

\section{Outer Context}

The teachers described that the way they interact and communicate with the students is not only determined by classroom context but other factors may intervene and shaped the face of relation, communication and interaction between teacher and students. 
Curriculum 2013 is quite different. The students need to practice first... (TW-05).

The previous curriculum which I first taught English did not require communication competence. In my opinion, the students are expected to comprehend. However, at this present, particularly curriculum 2013 requires them to be able to communicate and interact well. (TW-06).

The teachers reported that curriculum, school system, parent role, and exposure are some factors that influence how teachers build interaction and communication and how the students give responses. The model of classroom interaction in English as foreign language classes for lower secondary schools is displayed below.

\section{DISCUSSIONS}

From the emerged data, interaction in EFL classroom is not only verbal practices and non-verbal practices. Other dimensions, such as personal and pedagogical practices, are also apparent as one of characteristics of classroom communication. Teachers frequently use language to manage the class as well as building rapport between teacher and students. This may be consistent to second language classroom modes by Walsh (2011: 113). Managerial mode is one of classroom interaction features whose function is to organize the physical learning environment.

Moreover, the medium of instruction is differently described. The majority of the teachers prefer to combine first and target language with various proportion. The first language used in foreign language class is also reported by Petek (2013: 1195). Other teachers choose to use mostly in first for easiness and practicality. For beginning language learners, first language can be used to explain materials, discuss method of learning, and announce information that will be difficult to understand in target language (Harmer, 2007:132). Brown (2007: 119) also added that, for beginner, the main objectives of language learning is to comprehend and produce language in the controlled repertoire of language.

With regard to teacher talk, it is characterized by slow, clear and loud pace with simple expression in large quantities. This result support the findings by Walsh (2011: 6) and (Rashidi \& Rafieerad (2010: 93). Teacher's speech is typically slower, louder, more deliberate, and makes greater use of pausing and emphasis. Then, classroom communication is dominated by teacher speech to give instruction, explain activity, and check comprehension. In addition to speech, teachers also deliver questions, mainly displayed questions. This finding support that mostly teachers questions are in the form of displayed, close questions, rather than referential questions (Farahian \& Rezaee, 2012: 161; Petek, 2013: 1198; Pujiastuti, 2013: 171).

Concerning to handling errors, some teachers correct the errors made the students; meanwhile, other teachers feel that at some point errors need to be neglected. This finding supports the view by Brown (2007: 119) that as beginners, the students need to have plenty of time to produce language with no fear of being corrected. However, the teachers have to give feedback related to grammatical and phonological errors in order that the students do not always feel right. Discussing student response, the teachers said that

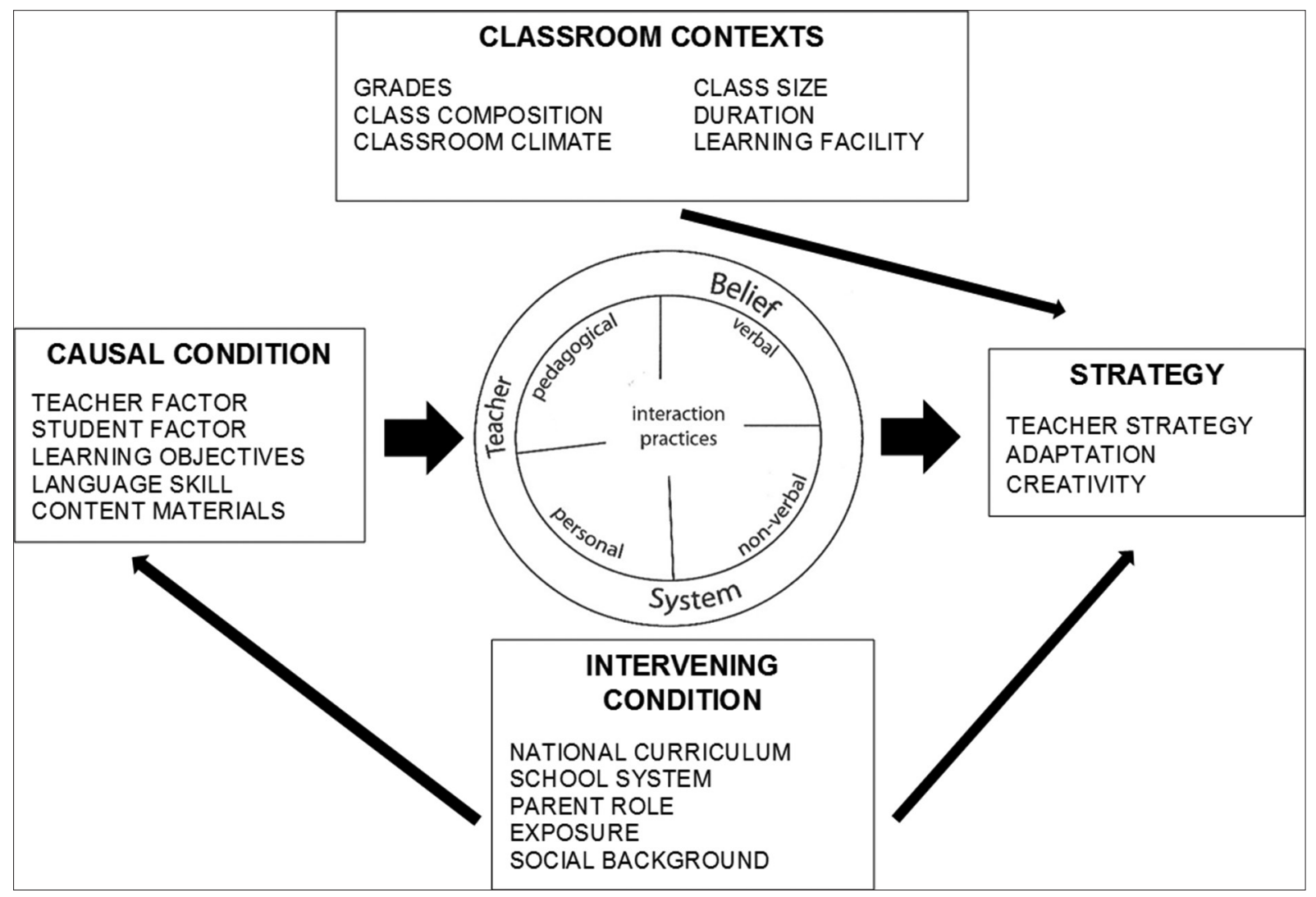

Figure 2. The Model of Classroom Interaction in EFL Classes for Lower Secondary Schools 
it is still limited in the form of short expression. Some of the students seem reluctant to use target language. These also consistent with the result of Nasruloh (2013: 142) and Savaşçı (2014: 2682). Nasruloh wrote that the students have a great opportunity to produce language, yet their production is still little and limited. Meanwhile, Savasci revealed that the students do not high willingness and desire to respond teacher's questions and rarely involve in conversation with teacher and other students. However, from this current research finding, the teachers believe that at this present the students, as beginners, provide limited language production; it is normal and natural. By the time, they gradually develop their language proficiency. Moreover, that the students are in silence does not indicate that they are not learning language. It seems that language learner needs a little time to comprehend and process what they listen and hear. And they provide responses when they feel they are ready. Just like what Yamat, Fisher, \& Rich (2013: 1337) stated, the students actually learn language even though they keep silent.

To build interaction with the students in foreign language, teacher has to be proficient enough. Language proficiency is one of the requirements as language teacher. At one side, it influences how the teacher interacts with the students. As the finding by Kang (2013: 149), the more teacher uses English in the classroom, the more students imitate and use it. Being proficient, the teacher can also stimulate the students to participate in oral interaction in the classroom (Consolo, 2006: 33). On the other hand, student factor may play prominent role in classroom interaction. Student's level of proficiency, character, intelligence, confidence and motivation are elements that may influence how students communicate and interact with others in the class. This finding support the views of some experts related to foreign language learning in general. Harmer (2007: 43) viewed that language learner has his own preferences. One student probably like creative writing and speaking activity, while others more enjoy structural activity. In addition to preferences, student confidence can be one of issues in language learning. Savaşçı (2014: 2686) found that feelings, such as less confident and afraid to made errors, are causes of the students are reluctant to participate in classroom communication.

Interaction in language classroom between teacher and students is primarily related to how teacher use language to check student comprehension. However, the teachers, mostly as initiators of interaction and communication, have several considerations underpinned their preferences in the classroom. Learning objectives and materials discussed in the classroom may bring the different modes of interaction. Moreover, contexts in the classroom, school and neighbor can probably give indirect effect to how teachers build communication and interaction. Teaching in large heterogeneous class with low-motivated students and lack of facility is, at some points, different to the one of small class with high-achievers completed by internet access and multimedia. To those classes, teachers select different language practice and activity, level of quantity and difficulty of materials, and learning objectives. Moreover, they differently use the type of questions, feedback, and error repair. Not only those elements, humors and compliment are carefully selected by the teachers; otherwise, they will bring disadvantageous and disruptive.

Furthermore, school system, curriculum, exposure, parent role and social background seemingly become indirect factors that influence of how teacher and students communicate and interact each other. Not too specific on interaction in language classroom, this research finding may support what has been extensively explained by Stern (1983, in Hall, 2011: 182-183) about contextual factors in language teaching. Stern noted that the school, institutional or educational system provides the immediate environment for the language class, affecting classroom practice by providing or instituting, for instance, the language learning curriculum and wider educational policies and values. Stern also added that the regional, national and international contexts for English language teaching and learning that may influence attitudes and policy, thereby affecting, both directly and in directly, what happens within educational institutions and the language class itself. In addition, the findings of this current research are also consistent to Seedhouse \& Jenks (2015) and (Thoms (2012)'s views of factors influencing classroom discourse. Interactions that take place inside the classroom, several variables outside of the classroom could affect discourse occurs in the classroom. Then, Seedhouse \& Jenks (2015) clarified by giving more explanation that classroom interaction might be inhibited or affected by policy from school, region or country, and it is also related to learner variables, linguistic or cultural background.

\section{CONCLUSION}

This present study investigates classroom interaction and several factors affecting it in foreign language classrooms at lower secondary schools based in teachers' perspectives. Classroom interaction is highly complex, yet it is central in language teaching learning process. The students acquire language through and in interaction with others, teacher and students. This current study aims at exploring interaction in language classroom in English as foreign language context at lower secondary schools from teacher perspectives. From dimension of verbal and non-verbal of interaction practices, teacher speech, questions, and feedback are emerged as dominance in overall classroom communication. In addition to verbal and non-verbal dimensions, pedagogical and personal dimensions arise the head to control and manage the classroom and to build rapport between teacher and students.

Furthermore, several factors, in and outside the classroom, may affect the way the teachers interact with the learners and the strategy they select in the classrooms. Learners and teacher variables, learning objectives, and targeted language skills are initial factors influencing classroom interaction. Secondly, classroom contexts can be specified as grades, composition, class size, duration and learning facility. Not only those factors, several external factors, as sociocultural background, arise out, such as adopted national curriculum, school system, parent role, language exposure and other social economic variables. In the other words, in general, classroom, institutional, and national contexts which are related to language teaching learning policy may 
influence, directly or indirectly, the language practices and activities in the class. In conclusion, they may bring implication to the teacher preferences when building interaction with the students and the classroom discourse itself.

\section{REFERENCES}

Brown, H. D. (2007). Teaching by Principles: An Interactive Approach to Language Pedagogy. New York: Pearson Education.

Consolo, D. A. (2006). Classroom oral interaction in foreign language lessons and implications for teacher development. Linguagem \& Ensino, 9(2), 33-55.

Creswell, J. W. (2012). Educational research: Planning, conducting, and evaluating quantitative and qualitative research. Educational Research (Vol. 4). Boston: Pearson Education. https://doi.org/10.1017/ CBO9781107415324.004

Ellis, R. (1991). The Interaction Hypothesis: A Critical Evaluation. In Regional Language Centre Seminar (pp. 1-46). Singapore: EDRS \& ERIC. Retrieved from http://eric. ed.gov/ERICWebPortal/recordDetail?accno=ED338037

Farahian, M., \& Rezaee, M. (2012). A Case Study of an EFL Teacher's Type of Questions: An Investigation into Classroom Interaction. Procedia - Social and Behavioral Sciences, 47, 161-167. https://doi.org/10.1016/j. sbspro.2012.06.631

Hall, G. (2011). Exploring English Language Teaching. Language in Action. New York: Routledge.

Harmer, J. (2007). The Practice of English Language Learning. Malaysia: Pearson Education Limited.

Hermanto, H. (2015). Understanding Teacher Talk to Support Students' Communicative Competence Hermanto. Jurnal Sosial Humaniora, 8(2), 143-159.

Kang, D. M. (2013). EFL teachers' language use for classroom discipline: A look at complex interplay of variables. System, 41(1), 149-163. https://doi.org/10.1016/j. system.2013.01.002

Kharaghani, N. (2013). Patterns of interaction in efl classrooms. In The Global Summit on Education (pp. 859864). Kuala Lumpur: WorldConferences.net.

Krashen, S. D. (1989). Language Acquisition and Langauge Education. UK: Prentice Hall.

Larsen-Freeman, D., \& Long, M. H. (1991). Input Modification and Second Language Comprehension. An Introduction to Second Language Acquisition Research.

Liskinasih, A. (2016). Corrective Feedbacks in CLT-Adopted Classrooms' Interactions. Indonesian Journal of Applied Linguistics, 6(1), 60-69. https://doi.org/10.17509/ ijal.v6i1.2662

Mackey, A., Abbuhl, R., \& Gass, S. M. (2012). Interactionist Approach. In S. M. Gass \& A. Mackey (Eds.), The Routledge Handbook of Second Language Acquisition (pp. 7-23). New York: Routlege Taylor \& Francis Group. https://doi.org/10.1017/S0272263112000423

Maolida, E. H. (2013). A Descriptive Study of Teacher's Oral Feedback In an ESL Young Learner Classroom in Indo- nesia. K@Ta,15(2),117-123. https://doi.org/10.9744/ kata.15.2.117-124

Mayo, M. D. P. G., \& Soler, E. A. (2013). Negociated Input and Output/Interaction. In J. Herschensohn \& M. Young-Scholten (Eds.), The Cambridge Handbook of Second Language Acquisition (p. 842). New York: Cambridge University Press.

Murray, D. E., \& Christison, M. (2011). What English Language Teachers Need to Know Volume I : New York: Taylor \& Fancis e-Libaray. https://doi.org/10.1093/elt/ccv002

Nasruloh, M. I. (2013). Teacher-Student Interaction in a Project-based Learning Classroom. Journal of English and Education, 1(1), 142-153.

Petek, E. (2013). Teacher's Beliefs about Classroom Interaction and their Actual Practices: A Qualitative Case Study of a Native and a Non-native English Teacher's In-class Applications. Procedia - Social and Behavioral Sciences, 70, 1195-1199. https://doi.org/10.1016/j.sbspro.2013.01.176

Pujiastuti, R. T. (2013). Classroom Interaction: An Analysis of Teacher talk and Student Talk in English for Young Learner (EYL). Journal of English and Education, 1(1), 163-172.

Rashidi, N., \& Rafieerad, M. (2010). Analyzing patterns of classroom interaction in EFL classrooms in Iran. Journal of Asia TEFL, 7(3), 93-120.

Roostini, K. E. (2011). A Reflection on Teacher Questioning Types. Indonesian Journal of Applied Linguistics, I(1), 9-22.

Savaşçı, M. (2014). Why are Some Students Reluctant to Use L2 in EFL Speaking Classes? An Action Research at Tertiary Level. Procedia - Social and Behavioral Sciences, 116, 2682-2686. https://doi.org/10.1016/j.sbspro.2014.01.635

Seedhouse, P., \& Jenks, C. J. (2015). International Perspectives on ELT Classroom Interaction. In C. J. Jenks \& P. Seedhouse (Eds.), International Perspectives on ELT Classroom Interaction (pp. 1-9). Hampshire: Palgrave MacMillan.

Swain, M. (2000). The Output Hypothesis and Beyond- Mediating Acquisition through Collaborative Dialogue. In Sociocultural Theory and Second Language Learning (pp. 97-114). https://doi.org/10.1093/icb/18.3.401

Thoms, J. J. (2012). Classroom Discourse in Foreign Language Classrooms : A Review of the Literature. Foreign Language Annals, 45(S1), 8-27. https://doi.org/10.111/j 1944-9720.2012.01177.x.FOREIGN

Ur, P. (2009). A Course in Language Teaching: Practice and Theory. UK: Cambridge University Press. https://doi. org/10.1017/CBO9781107415324.004

Walsh, S. (2011). Exploring Classroom Discourse: Language in Action. Oxon: Routlege Taylor \& Francis Group.

Yamat, H., Fisher, R., \& Rich, S. (2013). Young Malaysian Children's Silence in a Multicultural Classroom. Procedia - Social and Behavioral Sciences, 103, 1337-1343. https://doi.org/10.1016/j.sbspro.2013.10.464 